\section{The Impact of Cross-National Distance on Survival of Foreign Subsidiaries}

\author{
Fabio Cassio-de-Souza ${ }^{\dagger}$ \\ Programa de Mestrado e Doutorado em Gestão Internacional, ESPM, São Paulo, SP, Brazil \\ Mario Henrique Ogasavara $\Omega$ \\ Programa de Mestrado e Doutorado em Gestão Internacional, ESPM, São Paulo, SP, Brazil
}

\begin{abstract}
Survival of overseas subsidiaries is an important success indicator of foreign investments. Research on institutional approaches has been undertaken in this way, but generally restricted to a limited number of cross-national distances (CNDs). This research examines the impact of nine CNDs and local experience on subsidiary survival of foreign subsidiaries. Moreover, we tested the moderating effects of local experience on CND to analyze whether it could reduce these distances. Using a sample of 1,650 foreign subsidiaries established in 36 European countries, we applied Cox regression with a longitudinal analysis for the period 2007-2014. The results indicate that CND significantly affect subsidiary survival. Out of nine CND, four increase the risk of mortality, while one increases longevity. Local experience also plays a significant role for the continuity of the foreign operation in the local market, while moderating the impact between one CND and survival. These results can provide valuable information for strategic processes and better decision making of internationalization, and contribute to the success and survival of international operations.
\end{abstract}

Keywords: Cross-national distance, Foreign subsidiary, Survival, Internationalization, Longitudinal study.

\section{INTRODUCTION}

One aspect that deserves attention and is considered as a basic research objective of international business literature is firm performance (GLAUM; OESTERLE, 2007), which is one of the most important constructs in management research (KIRBY, 2005). Richard et al. (2009) stated that research has used three main firm performance measures: (i) objective measures, including accounting, financial market, sales, and market share; (ii) subjective measures, such as reputation, perception of effectiveness in terms of sales, and market share; (iii) survival - pertinent measurement to researchers and managers alike (DUNNE et al. 1988).

Survival has been used to examine how foreign subsidiaries have performed, since other measurements of performance at the subsidiary level are unavailable (GARG; DELIOS, 2007). Thus, survival and financial performance outcomes are closely related (BAKER;
Corresponding author:

† Programa de Mestrado e Doutorado em Gestão Internacional, ESPM, São Paulo, SP, Brazil.

E-mail: fabio.souza@espm.br

$\Omega$ Programa de Mestrado e Doutorado em Gestão Internacional, ESPM, São Paulo, SP, Brazil.

E-mail: mario.ogasavara@espm.br

Received: 03/10/2017. Revised: 05/10/2017. Accepted: 06/20/2017.

Published Online: 02/01/2018.

DOI: http://dx.doi.org/10.15728/bbr.2018.15.3.5 
KENNEDY, 2002). Furthermore, when firms internationalize some differences exist between home market and the host-country that receives foreign investment. Furthermore, when firms internationalize, certain differences exist between the home market and the host country that receives the foreign investment. This scenario has led scholars from the international business field to devote attention to cross-national distance (hereafter as CND), such as Berry (2010). Thus, analyzing the differences between countries in the diversity of institutional perspectives (JACKSON; DEEG, 2008) may represent a productive field for investigation.

By observing the liability of foreignness in a foreign market, Hymer (1960) indicated the importance of analyzing the differences between countries. Later, Dunning (1988) indicated that countries face objections beyond geographical boundaries to achieve success in another market. This study proposes that differences exist in terms of cultural, economic, political, and social aspects of the countries where multinational enterprises (MNEs) operate, and, consequently, that these differences might have an impact on subsidiary performance.

Despite being a widely used approach to CND in international business, cultural distance is one of the set proposals of the new institutional perspective. Hennart and Larimo (1998) stated that cultural difference is only one of the distances that influence transaction costs. Henisz (2000) affirmed that economic differences can foster the growth of MNE. Goerzen and Beamish (2003) considered that geography encounters obstacles to the growth of MNEs, so it impacts on subsidiary performance in costs (BOEH; BEAMISH, 2015). Kogut and Singh (1988) refer to cultural characteristics of the foreign market to measure distance between countries involved in the establishment of activities in that country.

Hence, analyzing the differences between countries based on recent institutional perspective (JACKSON; DEEG, 2008) can help firms to overcome difficulties in another country (KOSTOVA et al. 2008). It is confirmed that selected strategies should contribute to the success of foreign investments (PENG; BEAMISH, 2014). Gaur and Lu (2007) investigated the association of subsidiary survival and institutional distance, focusing the analysis on two distances.

However, there are more institutional distances to be considered in international business literature. Berry et al. (2010) provided a study that offers measurement for nine CNDs, following recent institutional theorizing in the field of international business, including distances related to administrative, geographic, demographic, knowledge, political, financial, global access, economic, and cultural aspects. By analyzing the diversity among countries, MNEs can understand the environment and the challenges (BAE; SALOMON, 2010) for all aspects, either concerning new investments or their maintenance (GAUR; LU, 2007).

Therefore, our study aims to answer the following research question: What is the impact of CND on the survival of foreign subsidiaries? In this way, this study investigates the CND influence on the continued existence of foreign subsidiaries and intends to contribute to the international business literature in four points. First, prior studies took into consideration only a few dimensions of CND in their investigation (BARKEMA et al. 1996; HUTZSCHENREUTER; HORSTKOTTE, 2013). Berry et al. (2010) showed the impact of a multidimensional CND approach on the choice of foreign market entry. They claimed that further studies could use this CND approach to resolve some of the inconsistencies reported in the literature concerning the effect of distance on firm performance. In this way, we extend their research by investigating how CNDs affect the survival of foreign subsidiaries. 
BBR

15,3

Second, while CND could direct influence firm performance, prior research suggests that experience could moderate this relationship (SLANGEN; HENNART, 2008; HUTZSCHENREUTER; HORSTKOTTE, 2013). Thus, we intend to empirically contribute to this aspect by analyzing whether local experience moderates the relationship between CND and subsidiary survival.

Third, previous studies on CND are based on cross-sectional analysis. However, there is a need for more longitudinal analyses, particularly on subsidiary performance. In this way, we apply a Cox Regression (COX; OAKES, 1984) using a longitudinal data of foreign subsidiaries that operate in European countries for the period of 2007-2014. We hope to find evidence regarding which CND matters for longevity of foreign operations, while benefiting by using a longitudinal analysis (HARZING, 2002).

Finally, by understanding which CND matters most to longevity, it would be possible to help managers focus their attention on such aspects, and, consequently, overcome difficulties and increase the likelihood of subsidiary longevity.

The paper is structured as follows. After presenting the introduction with the research question and contribution, we present the literature review and develop the hypotheses for this study in the next section. Later, we describe the methodological approach and present the empirical analysis and the discussion of the results. Finally, we conclude the paper in addition to discussing the limitations and suggestions for future research.

\section{LITERATURE REVIEW AND HYPOTHESES}

A company becomes a MNE when it decides to expand its activities beyond national boundaries and reach foreign markets, starting the internationalization process. International operations include a simple international trade via exports to another country or the establishment of a subsidiary in that country. In this way, internationalization is the process by which a company ceases to operate only in the limits of the domestic market and begins to explore foreign markets. The efficiency of investment allocation can find support in examining MNE survival. In the firm internationalization and strategic management literature, survival is treated as the continuation of the activities of an MNE subsidiary. Thus, examining subsidiary survival in foreign countries is an important indicator of the success of investments.

An organization needs to consider institutional multidimensionality when entering a new country (DIMAGGIO; POWELL, 1983), and there is a positive impact of institutional development on attractiveness to FDI (FERREIRA; FERREIRA, 2016). There is a need to look beyond cultural differences, behavior, values, standards, principles, and social influences to indicate the necessary adjustments to the successful expansion of MNEs and their existence (BERRY et al. 2010). Thus, researching firm internationalization based on institutional perspectives can increase the probability of survival (KOSTOVA et al. 2008). Furthermore, understanding cross-national distance between countries is important for companies whose operations cross-national borders (BAE; SOLOMON, 2010). This institutional approach supports structuring constructs that analyze the dimensions of the differences between countries (BERRY et al. 2010; GHEMAWAT, 2001). Consequently, previous research has contributed to the understanding of diversity among nations to analyze these dimensions and affect the decision on the internationalization process. We 
expect that this CND could also affect the survival of subsidiaries. In this way, we explore nine CND and propose hypotheses for each of them.

The first distance comprises the comparison between national business systems, which is defined as administrative distance. There are asymmetrical features in several aspects, including administrative standards (LA PORTA et al. 1998). For instance, nations are different when examining bureaucratic systems, colonizer-colonized relationship, common language, religion, and legislative systems (GULER; GUILLÉN, 2010; GHEMAWAT, 2001; HEINSZ, 2000). Administrative distance is not considered in the cultural and political measures, despite its conceptual proximity.

Formal and informal institutional arrangements that go beyond the purely political nature of the nation (BERRY et al. 2010) could threaten MNEs in the country. Therefore, the administrative aspects hold the strategy operation and selection of the country receiving foreign investment (BELDERBOS; ZOU; 2007; GOERZEN, 2007; LU; BEAMISH, 2004; $\mathrm{XU}$; SHENKAR, 2002). The existence of differences serves as a source of knowledge for gradualism and the formation of a network (JOHANSON; VAHLNE, 1977). Examining the administrative distance can help to elucidate the effectiveness of internationalization, and, consequently, its survival. Therefore:

H1: Administrative distance between countries is negatively associated with the hazard of subsidiary survival.

Geographical distance has a direct influence on business between countries impacting logistics and communication costs of information between headquarters and subsidiaries (DAI et al. 2013; GOERZEN; BEAMISH, 2003). Accessibility, distance, infrastructure, physical extension, time zone, logistics, climate, and topography are attributes associated with geographical distance. Thus, MNEs might be directly impacted by geographical issues in their costs of access to new countries (GHEMAWAT, 2001).

Based on gravitational theory, similar countries in terms of size and proximity tend to attract greater flow of trade. The opposite is also true, that those countries with larger geographical distance tend to present a smaller trade flow between them (FRANKEL; ROSE, 2002). Some studies advance in the analysis of geographical distances with different methods. For instance, using latitude and longitude in the study of trade and its impact, with the use of a large circle (BERRY et al. 2010) or straight lines (KRISHNA, 2003) to determine the distance between countries. Therefore, geographical aspects can affect the performance and profitability of the subsidiary (DELIOS; BEAMISH, 2001). It leads to the expectation that this geographical distance also impacts subsidiary survival, hence:

H2: Geographical distance between countries is negatively associated with the hazard of subsidiary survival.

Demographic aspects can identify the attractiveness of a country for MNE internationalization. Indicators allow the examination of differences between countries concerning the population and characteristics such as size, growth, age distribution, and social classes of each nation. The examination of the demographics of each country is an important aspect to capture the differences between nations and their dimensions (WHITLEY, 1992). 
BBR

15,3

288

Some indicators are used to determine the market attractiveness and growth potential. The analysis of the indexes of life expectancy, fertility, and population stratification attests fundamental characteristics of countries and highlights the differences between them (BERRY et al. 2010). In the international business area, the study of demographic indexes has been related to the selection of investments (WILLIAMS; GRÉGOIRE, 2014; ZHOU; GUILLÉN, 2014), but could be related to the success of the international investment. Hence:

H3: Demographic distance between countries is negatively associated with the hazard of subsidiary survival.

Different government systems are the basis for the political distance (HENISZ, 2000). Delios and Henizs (2003) argued the need to understand political institutions that constrain or allow disadvantages towards businesses. For instance, the governmental influence on the economy, political stability, democracy, and trade agreements impact the selection of country destination for foreign investments. Researchers have developed studies of political differences, comparing government systems and political instability for foreign market selection, sequential investments, and entry mode (DAI et al. 2013; GARCIA-CANAL; GUILLÉN, 2008; WAN, 2008).

Moreover, Delios and Henizs (2003) claimed that research on international strategy should emphasize an understanding of political institutions that constrain firm performance. By capturing political vulnerability, MNEs reduce legitimacy with local industries (OGASAVARA, 2014; PENG, 2012). It is natural that MNEs select countries with greater political stability (CHAN; MAKINO, 2007). Based on these arguments, the political aspects might impact subsidiary survival, hence:

H4: Political distance between countries is negatively associated with the hazard of subsidiary survival.

The financial distance relates to national economic development. The institutional literature addresses this issue in studies related to the levels of development of financial systems, access to credit, and the way companies finance their operations (LA PORTA et al. 1998). Differences in financial sector development level reflect the indicators of private credit systems, capital market, and the accessibility and financial openness of a nation. Consequently, the indicators have their use in combination with corporate governance, foreign investment, and acquisitions (FANG et al. 2013; CHUNG; BEAMISH, 2005). By analyzing the financial differences on this perspective, it could provide evidence of relationship to subsidiary survival, thus:

H5: Financial distance between countries is positively associated with the hazard of subsidiary mortality.

Researchers have examined the knowledge distance between countries in association with location choice of foreign investments (GULER; GUILLÉN, 2010). Previous studies examine the influence of levels of knowledge transfer on firm performance, organizational behavior(SOHN, 1994), and the relationship between knowledge and experience (POWELL; 
RHEE, 2013). Furthermore, it also investigates integration and knowledge transfer (FANG et al. 2013), local knowledge levels, and the influence of expatriates (PENG, 2012). We expect that knowledge distance also influence the subsidiary survival, consequently:

H6: Knowledge distance between countries is negatively associated with the hazard of subsidiary survival.

The ability to connect via tourism or over the Internet with other countries gives meaning to the global access and connectivity distance (BERRY et al. 2010). The environment facilitates certain nations to have access and disseminate information (GUILLÉN; SUAREZ, 2005 ) to other countries and contributes as an inheritance to the company network (BERRY et al. 2014). The examination of the global distance can provide clues about the reduction of uncertainty, probability of exit, irreversibility of investments (SONG, 2014), and its relationship to the development of experience (BERRY, 2015; WANG; LARIMO, 2015). Therefore:

H7: Global connectivity distance between countries is negatively associated with the hazard of subsidiary survival.

Economic differences between countries are important indicators to consider for foreign investments. Economic distance relates to the economic development and macroeconomic characteristics, including inflation, income, trade balance - imports versus exports, as measurement indicators of such distance (CHUNG; LU; BEAMISH, 2008). Therefore, aggregating these indicators could express the economic potential and wealth of a nation. The economic distance between countries focuses on the levels of trade and the types of partners that each country can attract (GHEMAWAT, 2001). The country selection from this perspective can present challenges for the maintenance of international activities. It is possible that MNEs find economic distance as an indicator that supports the adoption of strategic decisions and increases the likelihood of survival, thus:

H8: Economic distance between countries is negatively associated with the hazard of subsidiary survival.

Finally, cultural distance has attracted attention in the international business field, as most researchers have already used it in empirical investigation, particularly with contributions for the strategic selection of markets and locations, managerial decisions, and entry mode. Examining cultural distance could provide a better understanding of the differences between the parent company and its affiliates. In addition, it can contribute to reducing uncertainty and expansion costs in firm internationalization (HENNART; LARIMO, 1998; KOGUT; SINGH, 1988).

Moreover, the investigation of cultural distance can provide the understanding of the differences between countries and their firms' relationships to assist strategic aspects of MNEs. For instance, a Japanese company selects a European country to establish a subsidiary, considering cultural differences between the parent firm and subsidiary. French employees working at Citibank Company in France consider the French culture. Americans 
BBR

15,3

290

who work at Toyota bring American culture to the U.S. subsidiary of the Japanese company (CAPRAR, 2011). Thus, the relationship between cultural distance and the subsidiary survival might reveal important indicators for managerial aspects to understand the longevity of its international operations, therefore:

H9: Cultural distance between countries is negatively associated with the hazard of subsidiary survival.

Multinational firms can properly exploit the capabilities and resources of their subsidiaries to transfer knowledge (BERRY, 2015). The local subsidiary's experience can be an indicator of multinational capabilities (GAUR; LU, 2007) and provide an informational advantage on the transfer of resources into organizational practices (DELIOS; BEAMISH, 1999; KOSTOVA, 1999) and knowledge (BERRY, 2015; SOHN, 1994), and obtains local legitimacy. The experience supports to elucidate the subsidiary longevity and business practice in another country with the challenge of liability of knowledge of the local market (HENNART, 1991). Flexibility seems to be the answer for the adaptation of the firm to the environment (ROMAN et al. 2012), and the development of local experience appears to play a main role in the company's survival in another country (WANG; LARIMO, 2015; YIU; MAKINO, 2002). Delios and Henisz (2003) showed the effect of experience as a means to reduce the sensitivity to institutional differences. In this way, we proposed the following hypothesis:

\section{H10: Local experience is positively associated with the hazard of subsidiary survival.}

As mentioned earlier, local experience is expected to have a direct and positive influence on subsidiary performance. However, other aspects related to the institutional environment could have a key role to the structure and organizational behavior. For instance, Hsu and Pereira (2008) found the importance of the moderation effect of organizational learning on internationalization and performance. In the internationalization process, organizational learning could be associated with the local experience or local institutional knowledge (JAVERNICK-WILL, 2009).

Some authors have elucidated that the evolvement of this local knowledge, or international experience, is a key role for subsidiary survival in international markets (WANG; LARIMO, 2015; YIU; MAKINO, 2002). According to Delios and Henisz (2003), a firm tries to accumulate experience prior to entering hazardous countries. Additionally, the experience could provide important ownership advantages such as management practices, patents, technology, and management skills (DUNNING; LUNDAN, 2008). Hutzschenreuter and Horstkotte (2013) found that international experience attenuates the negative effect of cultural distance on firm performance. Thus, it is expected that local experience could moderate the impact of CND on the subsidiary longevity, thus:

H11: Local experience moderates the relationship between CNDs and the hazard of subsidiary survival. 


\section{METHODOLOGY}

The scope of this research is to examine the survival of foreign MNE subsidiaries established in European countries by applying the perspective of CND, local experience, and their moderating effects. The investigation of subsidiary longevity with institutional approach to CND may indicate an important field for the international business field (GAUR; LU, 2007).

We used secondary database published by Toyo Keizai. The publication is the data diffusion of Japanese investments in other countries since 1970, which is widely used in international business research (DUTTA; BEAMISH, 2013; JIANG et al. 2014).

We used Japanese subsidiaries as a background to test our hypotheses based on the following aspects. First, Japan is the fifth largest foreign investor during the period 1970-2012 (UNCTAD, 2015), after the U.S., the U.K., France, and Germany. Moreover, Japan is the only Asian country to be among the top five in outflow foreign direct investments (FDIs). Second, Japanese companies are considered in the ranking of the Fortune Global 500, which lists 62 firms among the 500 largest in the world. Third, the availability of data at the subsidiary level is very limited. Most of the available data consists of the firm level and aggregate data. Thus, this is an opportunity to use a database of Japanese subsidiaries to test empirically many critical issues on international business literature, such as CND. Finally, Japanese MNEs serve as an object of research for several studies in the international business field (OGASAVARA, 2014; ANDO; ENDO, 2013; BELDERBOS; ZOU, 2009; WAN, 2008).

The selection to analyze foreign investment in European countries during the period 2007-2014 is motivated by the following reasons. The period of analysis covers a recent transformation that the European continent has experienced in terms of economic aspects concerning the crisis with political and institutional changes. Based on these arguments, it would be an appropriate time and context to investigate the cross-national effects on survival of these international operations.

We applied the survival analysis, implementing Cox Regression (COX; OAKES, 1984). Our dependent variable is subsidiary survival. The analyzed event is failure, while survival is the continuity of data. There is another important concept in survival analysis, the hazard ratio. This is a risk assessment that is considered essential to perform the survival analysis. The focus is to investigate the probability of influence of the independent variables on the subsidiary survival (OGASAVARA; HOSHINO, 2008). The model has its description as follows:

$$
\mathrm{h}(\mathrm{t})=[\mathrm{h} 0(\mathrm{t})] \exp \left(\beta 1_{\mathrm{x} 1}+\ldots+\beta \mathrm{k}_{\mathrm{xk}}\right)
$$

where $\mathrm{h} 0(\mathrm{t})$ is a function of survival time baseline, and only depends on the time as $\beta 1_{\mathrm{x} 1}$ $+\ldots \mathrm{Bk}_{\mathrm{xk}}+1$ is dependent on the contents of the independent variables and the coefficients obtained with the regression. As some variables in the model have an influence variation in time, the variables were introduced in the formula $z_{i}(t)=z_{i g}(t)$. 


$$
h(t)=[h 0(t)] \exp \left\{\beta 1_{x 1}+\ldots+\beta k_{x k}+g(t)\left(\gamma i_{z i}+\ldots+\gamma m_{z m}\right)\right\}
$$

where $(\mathrm{zi}, \ldots, \mathrm{zm})$ are time-dependent variables and the estimate has the net effect of a regression coefficient estimated $\gamma \mathrm{i}$ for a covariate $\mathrm{g}(\mathrm{t}) \mathrm{zi}$, which is a function of the time limit of examination, the year 2014.

The regression analysis shows variables that positively or negatively contribute to the subsidiary survival. The advantage that the hazard ratio has any relationship to not only considers the total number of subsidiaries linearly, but also addresses the observation time. This technique demonstrates effectiveness in cases where there is no uniformity of time, a characteristic found in the survival analysis.

The independents variables are nine CND and local experience. The eight CND data were collected through CIBER - Center for International Business Education and Research of Wharton Business School (LAUDER INSTITUTE, 2015). The CND for cultural distance data were collected through the website of The Hofstede Centre (HOFSTEDE, 2010). The other independent variable is local experience, which measures total experience (in years) of the subsidiary in the local market. For this information, we considered the year of entry declared in the country in the Toyo Keizai dataset, which is the beginning of the activities of that subsidiary.

We selected 36 European countries that include Austria, Belgium, Bosnia and Herzegovina, Bulgaria, Croatia, Czech, Denmark, Estonia, Finland, France, Germany, Greece, Hungary, Ireland, Italy, Latvia, Lithuania, Luxembourg, Macedonia, Montenegro, Netherlands, Norway, Poland, Portugal, Principality of Monaco, Romania, Russia, Serbia, Slovakia, Slovenia, Spain, Sweden, Switzerland, Turkey, Ukraine, and the United Kingdom.

We used the control variable related to the size of the subsidiary, country, and continent. To determine subsidiary size, it considers the number of employees reported in the directory of Toyo Keizai data. The subsidiary size corresponds to the proportion of investments in the host country, and a great demand size subsidiary means a greater commitment to the parent firm to that unit (OGASAVARA; HOSHINO, 2008).

The sample with 14,247 observations from foreign subsidiaries was subjected to preliminary tests and analyses to verify the correlation indices between the variables. The correlation results can be seen in Table 1 . The index revealed a very weak degree of correlation between the variables (COHEN, 1988) and did not indicate correlation problems.

Table 1. Sample descriptive statistics and correlations $(\mathrm{N}=14247)$

\begin{tabular}{|c|c|c|c|c|c|c|c|c|c|c|c|}
\hline Variables & 1 & 2 & 3 & 4 & 5 & 6 & 7 & 8 & 9 & 10 & 11 \\
\hline 1. Administrative & 1.000 & & & & & & & & & & \\
\hline 2. Geographic & -0.236 & 1.000 & & & & & & & & & \\
\hline 3. Demographic & 0.231 & -0.526 & 1.000 & & & & & & & & \\
\hline 4. Political & 0.017 & -0.064 & 0.321 & 1.000 & & & & & & & \\
\hline 5. Financial & 0.174 & -0.567 & 0.567 & 0.100 & 1.000 & & & & & & \\
\hline 6. Knowledge & 0.146 & 0.048 & 0.451 & 0.444 & -0.083 & 1.000 & & & & & \\
\hline 7. Global & 0.206 & -0.641 & 0.472 & 0.047 & 0.364 & 0.130 & 1.000 & & & & \\
\hline 8. Economic & 0.072 & -0.317 & 0.559 & 0.135 & 0.442 & 0.172 & 0.079 & 1.000 & & & \\
\hline 9. Cultural & 0.196 & -0.165 & 0.088 & -0.029 & -0.341 & 0.273 & 0.073 & -0.008 & 1.000 & & \\
\hline 10. Local & -0.064 & 0.142 & -0.176 & 0.067 & -0.152 & -0.011 & -0.140 & -0.129 & -0.009 & 1.000 & \\
\hline 11. Size & -0.003 & -0.004 & 0.000 & -0.016 & 0.051 & -0.032 & -0.021 & 0.025 & -0.031 & 0.020 & 1.000 \\
\hline
\end{tabular}




\section{EMPIRICAL ANAYSIS AND DISCUSSION}

The results (Table 2) confirm the impact of five out of nine CNDs on subsidiary survival. The models were run separately, considering the effect of each distance and local experience with the control variables (Models 1 to 9). The results highlight that five distances were significant. Four distances (i.e., administrative, geographic, global connectivity and economic) have not reached the expected level of significance, which do not support H1, H2, H7, and H8. The findings show that CNDs related to demographic, political, financial, and knowledge negatively impact subsidiary survival, while cultural distance has a positive impact on survival.

Table 2. Results of Cox Regression (+ = higher survival)

\begin{tabular}{|c|c|c|c|c|c|c|c|c|c|}
\hline Variables & Mod 1 & $\operatorname{Mod} 2$ & Mod 3 & $\operatorname{Mod} 4$ & Mod 5 & Mod 6 & $\operatorname{Mod} 7$ & Mod 8 & Mod 9 \\
\hline \multicolumn{10}{|l|}{ Independent variables } \\
\hline Local experience & $\begin{array}{c}+2.74^{* * *} \\
(1.0039)\end{array}$ & $\begin{array}{c}+2.74^{* * *} \\
(1.0039)\end{array}$ & $\begin{array}{c}+2.75^{* * *} \\
(1.0040)\end{array}$ & $\begin{array}{c}+2.70^{* * *} \\
(1.0039)\end{array}$ & $\begin{array}{c}+2.74^{* * *} \\
(1.0039)\end{array}$ & $\begin{array}{c}+2.48^{* * *} \\
(1.0036)\end{array}$ & $\begin{array}{c}+2.73^{* * *} \\
(1.0039)\end{array}$ & $\begin{array}{c}+2.74^{* * *} \\
(1.0039)\end{array}$ & $\begin{array}{c}+2.78^{* * *} \\
(1.0040)\end{array}$ \\
\hline \multicolumn{10}{|l|}{ CND } \\
\hline Administrative & $\begin{array}{c}-1.49 \\
(0.9950)\end{array}$ & - & - & - & - & - & - & - & - \\
\hline Geographic & - & $\begin{array}{l}+0.59 \\
(1.000)\end{array}$ & - & - & - & - & - & - & - \\
\hline Demographic & - & - & $\begin{array}{c}-3.32^{* * *} \\
(0.9811)\end{array}$ & - & - & - & - & - & - \\
\hline Political & - & - & - & $\begin{array}{c}-8.12^{* * *} \\
(0.9998)\end{array}$ & - & - & - & - & - \\
\hline Financial & - & - & - & - & $\begin{array}{c}-1.82^{*} \\
(0.9716)\end{array}$ & - & - & - & - \\
\hline Knowledge & - & - & - & - & - & $\begin{array}{c}-2.72^{* * *} \\
(0.9916)\end{array}$ & - & - & - \\
\hline Global & - & - & - & - & - & - & $\begin{array}{c}-0.05 \\
(0.9981)\end{array}$ & - & - \\
\hline Economic & - & - & - & - & - & - & - & $\begin{array}{c}-0.38 \\
(0.9969)\end{array}$ & - \\
\hline Cultural & - & - & - & - & - & - & - & - & $\begin{array}{c}+2.66^{* * *} \\
(1.0623)\end{array}$ \\
\hline \multicolumn{10}{|l|}{ Control variable } \\
\hline Size & $\begin{array}{c}-0.11 \\
(0.9977)\end{array}$ & $\begin{array}{c}-0.13 \\
(0.9974)\end{array}$ & $\begin{array}{c}-0.10 \\
(0.9980)\end{array}$ & $\begin{array}{c}-0.31 \\
(0.9937)\end{array}$ & $\begin{array}{c}-0.12 \\
(0.9975)\end{array}$ & $\begin{array}{c}+0.02 \\
(1.0004)\end{array}$ & $\begin{array}{c}-0.13 \\
(0.9973)\end{array}$ & $\begin{array}{c}-0.12 \\
(0.9976)\end{array}$ & $\begin{array}{c}-0.04 \\
(0.9992)\end{array}$ \\
\hline Number observations & 14.725 & 14.725 & 14.749 & 14.749 & 14.766 & 14.399 & 14.749 & 14.749 & 14.686 \\
\hline Number of failures & 749 & 749 & 749 & 749 & 744 & 727 & 749 & 749 & 748 \\
\hline Log likelihood & -7138.3 & -7139.4 & -7134.9 & -7106.0 & -7087.1 & -6910.8 & -7141.0 & -7140.9 & -7124.3 \\
\hline LR chi square & 26.95 & 24.80 & 36.22 & 94.17 & 28.11 & 29.80 & 24.17 & 24.31 & 31.82 \\
\hline Significance & 0.0000 & 0.0000 & 0,0000 & 0,0000 & 0.0000 & 0,0000 & 0.0001 & 0.0001 & 0,0000 \\
\hline
\end{tabular}

Notes: Hazard ratio in parenthesis.

${ }^{*}$ significant at $10 \%$ level; ${ }^{* *}$ significant at $5 \%$ level; ${ }^{* * *}$ significant at $1 \%$ level.

Source: the authors.

The characteristics presents in Demographic CND can highlight the existing challenge between different countries that the firm should consider for its effectiveness. Thus, firms from countries with more demographic differences may consider it as a threat to survival or foreign investment (TSANG; YIP, 2007). Thereby, it may not be enough to consider aspects restricted to the attractiveness of the market (MALHOTRA et al. 2009) but rather to also consider demographic characteristics that are distinct between countries and transition economies (MA; DELIOS, 2007). The results supported H3 and are consistent to other studies (FANG et al. 2013). 
BBR

15,3

294

The Political CND shows a negative association to the hazard of subsidiary survival ( $p<0.01$ ), supporting H4. It means that this distance is a threat to subsidiary survival, implying that politically distant countries tend to cause a greater threat to their adaptation. Firms that have followed a sequential process of international expansion are less sensitive to the impact of political risks (DELIOS; HENIZS, 2003). The findings corroborate to the findings of Dai et al. (2013), who emphasized the severe impact of the political differences for survival in different countries for the home market. In addition, Delios and Henisz (2003) stated that the political distance can be a problem for multinational companies to adapt and, thus, impede their continuity.

The findings support H5 by confirming the negative relationship between Financial CND and subsidiary survival $(\mathrm{p}<0.10)$. The result is similar to the results of Chung and Beamish (2005), Tsang and Yip (2007), and Fang et al. (2013), which indicated that divergent indicators of this distance are institutional obstacles to the success of foreign market operations. Delios and Henisz (2003) argued that Japanese firms appear to make investment decisions regardless of the level of uncertainty in the host environment and when considering financial aspects.

Subsidiaries are more likely to fail when finding greater differences on the Knowledge CND ( $<<0.01)$, giving support to H6. It means that this CND is a threat to subsidiary survival and is similar to the results of Fang et al. (2013), and Lu and Beamish (2004). They revealed that country differences matter when transferring knowledge to the subsidiary.

An interesting result is related to the Cultural CND. It presents an inverse implication than expected in H9. The findings show that cultural distance is positively associated to subsidiary survival $(\mathrm{p}<0.01)$. This implies that countries with higher cultural distance exhibit a higher likelihood of subsidiary survival. Some researchers have highlighted such findings as likely. According to Barkema et al. (1996), firms that have ventured into more culturally distant countries had a lower incidence of continued failure. The explanation for this unexpected result may be related to learning strategies and knowledge transfer (KOSTOVA, 1999), property and operational experience as a form to reduce the impact of this difference (DELIOS; BEAMISH, 2001), or use of expatriates (COLAKOGLU; CALIGIURI, 2008).

Furthermore, the results demonstrate a meaningful connection between local experience and survival. Experiential knowledge has a positive impact on subsidiary longevity $(p<0.001)$, which means that the growth of local experience increases the likelihood of subsidiary survival, supporting H10. This provides opportunities for accumulated experience to be transferred to its knowledge to deal with business operations. The findings are consistent with studies by Powell and Rhee (2013) and Gaur and Lu (2007), and enhance the effect of local experience as a noteworthy resource to reduce the sensitivity to institutional differences (DELIOS; HENISZ, 2003).

Finally, we analyzed whether the moderating effect of the local experience could reduce the impact of CNDs on subsidiary survival. According to Table 3, only the moderation between local experience and Economic CND show a significant relationship $(p<0.10)$. It implies that local experience moderates the negative effect between the economic distance between countries and subsidiary survival. As the experience in the local market increases, the effect of economic distance becomes lower for subsidiary longevity. In this way, it partially supports H11. 
Table 3. Results of Cox Regression with moderating effects (+ = higher survival)

\begin{tabular}{|c|c|c|c|c|c|c|c|c|c|}
\hline Variables & Mod 1a & $\operatorname{Mod} 2 \mathrm{a}$ & Mod 3a & Mod 4a & Mod 5a & Mod 6a & Mod 7a & Mod 8a & Mod 9a \\
\hline Local experience & $\begin{array}{c}+2.74^{* * *} \\
(1.0039)\end{array}$ & $\begin{array}{c}+2.73^{* * *} \\
(1.0039)\end{array}$ & $\begin{array}{c}+2.75^{* * *} \\
(1.0040)\end{array}$ & $\begin{array}{c}+2.73^{* * *} \\
(1.0039)\end{array}$ & $\begin{array}{c}+2.89^{* * *} \\
(1.0042)\end{array}$ & $\begin{array}{l}+2.44^{* *} \\
(1.0035)\end{array}$ & $\begin{array}{c}+2.73^{* * *} \\
(1.0039)\end{array}$ & $\begin{array}{c}+2.73^{* * *} \\
(1.0039)\end{array}$ & $\begin{array}{c}+2.79^{* * *} \\
(1.0040)\end{array}$ \\
\hline \multicolumn{10}{|l|}{ CND } \\
\hline Administrative & $\begin{array}{c}-0.26 \\
(0.9986)\end{array}$ & - & - & - & - & - & - & - & - \\
\hline Geographic & - & $\begin{array}{c}+0.60 \\
(1.0000)\end{array}$ & - & - & - & - & - & - & - \\
\hline Demographic & - & - & $\begin{array}{c}-2.53^{* *} \\
(0.9776)\end{array}$ & - & - & - & - & - & - \\
\hline Political & - & - & - & $\begin{array}{c}-4.26^{* * *} \\
(0.9998)\end{array}$ & - & - & - & - & - \\
\hline Financial & - & - & - & - & $\begin{array}{c}-0.94 \\
(0.9771)\end{array}$ & - & - & - & - \\
\hline Knowledge & - & - & - & - & - & $\begin{array}{l}-2.42^{* *} \\
(0.9873)\end{array}$ & - & - & - \\
\hline Global & - & - & - & - & - & - & $\begin{array}{c}-0.54 \\
(0.9722)\end{array}$ & - & - \\
\hline Economic & - & - & - & - & - & - & - & $\begin{array}{c}-1.67^{*} \\
(0.9781)\end{array}$ & - \\
\hline Cultural & - & - & - & - & - & - & - & - & $\begin{array}{c}+2.61^{* * *} \\
(1.1027)\end{array}$ \\
\hline Size & $\begin{array}{c}-0.11 \\
(0.9977)\end{array}$ & $\begin{array}{c}-0.14 \\
(0.9972)\end{array}$ & $\begin{array}{c}-0.09 \\
(0.9981)\end{array}$ & $\begin{array}{c}-0.31 \\
(0.9937)\end{array}$ & $\begin{array}{c}-0.11 \\
(0.9977)\end{array}$ & $\begin{array}{c}+0.03 \\
(1.0006)\end{array}$ & $\begin{array}{c}-0.13 \\
(0.9973)\end{array}$ & $\begin{array}{c}-0.12 \\
(0.9976)\end{array}$ & $\begin{array}{c}-0.05 \\
(0.9889)\end{array}$ \\
\hline \multicolumn{10}{|l|}{ Moderation } \\
\hline Experience $\mathrm{x}$ Administrative & $\begin{array}{c}-0.79 \\
(0.9997)\end{array}$ & - & - & - & - & - & - & - & - \\
\hline Experience x Geographic & - & $\begin{array}{c}-0.30 \\
(0.9999)\end{array}$ & - & - & - & - & - & - & - \\
\hline Experience x Demographic & - & - & $\begin{array}{c}+0.53 \\
(1.0003)\end{array}$ & - & - & - & - & - & - \\
\hline Experience x Political & - & - & - & $\begin{array}{c}-0.80 \\
(0.9999)\end{array}$ & - & - & - & - & - \\
\hline Experience $\mathrm{x}$ Financial & - & - & - & - & $\begin{array}{c}-0.30 \\
(0.9994)\end{array}$ & - & - & - & - \\
\hline Experience x Knowledge & - & - & - & - & - & $\begin{array}{c}+1.01 \\
(1.0002)\end{array}$ & - & - & - \\
\hline Experience x Global & - & - & - & - & - & - & $\begin{array}{c}+0.73 \\
(1.0023)\end{array}$ & - & - \\
\hline Experience $\mathrm{x}$ Economic & - & - & - & - & - & - & - & $\begin{array}{l}+1.95^{*} \\
(1.001)\end{array}$ & - \\
\hline Experience x Cultural & - & - & - & - & - & - & - & - & $\begin{array}{c}-1.22 \\
(0.9977)\end{array}$ \\
\hline Number observations & 14.725 & 14.725 & 14.749 & 14.749 & 14.666 & 14.399 & 14.749 & 14.749 & 14.686 \\
\hline Number of failures & 749 & 749 & 749 & 749 & 744 & 727 & 749 & 749 & 748 \\
\hline Log likelihood & -7137.9 & -7139.3 & -7134.8 & -7105.6 & -7087.1 & -6910.3 & -7140.7 & -7142.8 & -7123.5 \\
\hline LR chi square & 27.66 & 24.87 & 36.48 & 94.82 & 28.20 & 30.80 & 24.64 & 20.41 & 33.45 \\
\hline Significance & 0.0000 & 0.0001 & 0.0000 & 0.0000 & 0.0005 & 0.0000 & 0.0000 & 0.0004 & 0.0000 \\
\hline
\end{tabular}

Notes: Hazard ratio in parenthesis.

${ }^{*}$ significant at $10 \%$ level; ${ }^{* *}$ significant at $5 \%$ level; ${ }^{* * *}$ significant at $1 \%$ level.

Source: the authors. 
BBR

15,3

296

Some general discussions about our findings in the empirical analysis could be realized. First, one implication of this research is that CNDs and local experience matter to understand the longevity of foreign subsidiaries. Moreover, local experience is an important factor to moderate differences related to economic aspects between countries. Evans and Mavondo (2002) argued that when managers are responsible for a decision involving countries, they must exert greater efforts to understand foreign markets. Our study provides the benefits of recognizing multidimensional CNDs as important indicators for subsidiary survival. By using more than one CND, it is possible to better analyze which distance would be valuable to support decision making in international business and, consequently, increase the likelihood of survival of foreign operations in different markets.

Second, this highlights that higher distance demands an increase in the scope of market research and planning (EVANS; MAVONDO, 2002). This also establishes a reliable basis for managerial decisions involving distant countries (DIKOVA, 2009). Therefore, the process of market selection can achieve strong benefits using multidimensional CNDs, providing information to the MNEs to be prepared to answer, confront, and fit their goals towards market challenge levels.

Finally, by using longitudinal information, managers can better engage in strategies for subsidiary survival, select markets with more accuracy, decide the entry mode, and become more effective in international business operations.

\section{CONCLUSION}

This paper investigates the relationship of CND and local experience on subsidiary longevity. The findings contribute to the understanding of how subsidiaries are impacted by CND among the countries involved in the relationship between the parent firm and its subsidiary in different markets. Some points need to be highlighted concerning the contribution to the international business field.

First, the empirical nature of this research broadens the investigation of survival with many CND aspects. It extended prior studies by exploring multiple dimensions of distances on firm performance (BERRY et al. 2010), while providing a better understanding about which kind of external institutional measures are relevant to subsidiary survival. Due to the instability and uncertain environment of international business, it is important to consider the external institutional aspects with long-time observation, compared to internal aspects (KOSTOVA; ZAHEER, 1999). It shows the existence of a promising field of research on the action of CND and survival analysis.

Second, the accumulation of local experience concentrates another important aspect for decreasing the hazard of mortality. Although prominently invested in the examination of survival, no prior study had expanded the local experience in many constructs in the field of CND. This research shows the possibility of investigating this perspective and contributes in this direction. Moreover, although we analyzed different moderation effects of local experience and CND, our findings validate that accumulated experience in the local market moderates the negative relationship between economic distance and subsidiary survival. This finding extended those of previous studies (HUTZSCHENREUTER; HORSTKOTTE, 2013; DIKOVA, 2009). Future studies could broaden empirical analysis by testing other variables that could moderate the relationship between CND and firm performance. 
Third, the findings indicate that five CND play a key role in understanding the subsidiary longevity. It implies the similarities analysis decision and the inequalities between countries involved in the internationalization process. It is necessary that MNEs analyze the differences between countries in-depth, and take into consideration how extreme is the range of CND, as individual observations of its elements. In this way, might be better strategically advance to understanding of these distances and the confrontation scenario for firm survival.

Fourth, through a longitudinal analysis, we found more precise evidence about which CNDs matter for subsidiary survival, compared to cross-sectional analysis. Due to the lack of understanding the different institutional perspectives involved in international business, we encourage researchers to use multidimensional CNDs in longitudinal analysis for future studies. Engaging in an analysis over an extended period helps to elucidate the internationalization phenomenon.

As a managerial contribution, the results show important evidence of CND and may provide relevant information to managers concerning the strategic and decision-making processes. Survival in the market exceeds financial performance barriers, as there are constructs related to CND that can contribute to the success in operating internationally. Therefore, CND has been considered due to the risk of investment in the selection of countries for the establishment of foreign subsidiaries.

For the academic implications, it is expected that these findings will encourage the development of more research on institutional approaches. We need to better understand how CND relates among them and other variables, and not only restricted to subsidiary survival.

Although this study provides important findings for international business literature, this research presents some limitations. First, only exogenous features, or external environment variables, of the CNDs were applied. Investigating endogenous features in interaction with exogenous may provide opportunities for further research. Second, our analysis is based on subsidiaries of Japanese firms in European countries, which could have an influence on certain special characteristics of these multinational firms or with the specific context of this region. Future studies may look to different regions, country of origin of the MNEs, and time management to confirm our findings or even reveal other discoveries. Third, due to the availability of data, we could not control for firm industries. Some industries could be less sensitive to CND. Further studies could control for differences related to industry sector.

Furthermore, it indicates that future research should investigate the relationship with expatriates, entry mode, and the ability to adapt, learn, and transfer knowledge among MNE networks. Many of challenges could be exploited in further research to analyze in-depth the impact of diversity between countries and maximize the likelihood of attaining success in the internationalization process.

\section{REFERENCES}

ANDO, N.; ENDO, N. Determinants of foreign subsidiary staffing by service firms. Management Research Review, 36(6), 548-561, 2013.

BAE, J-H; SALOMON, R. Institutional distance in international business research. In: The past, present and future of international business \& management. Emerald Group Publishing Limited, 327-349, 2010.

BAKER, G.P.; KENNEDY, R.E. Survivorship and the economic grim reaper. Journal of Law, Economics and Organization, 18(2): 324-361, 2002. 
BBR

15,3

298
BARKEMA, H. G.; BELL, J. HJ; PENNINGS, J. M. Foreign entry, cultural barriers, and learning. Strategic Management Journal, 17(2): 151-166, 1996.

BELDERBOS, R.; ZOU, J. On the growth of foreign affiliates: multinational plant networks, joint ventures, and flexibility. Journal of International Business Studies, 38(7), 1095-1112, 2007.

BERRY, H. Knowledge Inheritance in Global Industries: The Impact of Parent Firm Knowledge on the Performance of Foreign Subsidiaries. Academy of Management Journal, 58(5): 1438-1458, 2015.

BERRY, H.; GUILLÉN, M.; HENDI, A. Is there convergence across countries? A spatial approach. Journal of International Business Studies, 45(4): 387-404, 2014.

BERRY, H.; GUILLÉN, M.; ZHOU, N. An Institutional Approach to Cross-National Distance. Journal of International Business Studies, 41(9): 1460-1480, 2010.

BOEH, K. K.; BEAMISH, P.W. The cost of distance on subsidiary performance. Asian Business \& Management, 14(3): 171-193, 2015.

CAPRAR, D. Foreign locals: A cautionary tale on the culture of MNC local employees. Journal of International Business Studies, 42(5), 608-628, 2011.

CHAN, C.; MAKINO, S. Legitimacy and multi-level institutional environments: Implications for foreign subsidiary ownership structure. Journal of International Business Studies, 38(4): 621-638, 2007.

CHUNG, C.; BEAMISH, P. Investment mode strategy and expatriate strategy during times of economic crisis. Journal of International Management, 11(3): 331-355, 2005.

CHUNG, C.; LU, J.; BEAMISH, P. Multinational networks during times of economic crisis versus stability. Management International Review, 48(3): 279-296, 2008.

COHEN, J. Statistical power analysis for the behavioral sciences. Lawrence Earlbaum Associates. Hillsdale, NJ, 20-26, 1988.

COLAKOGLU, S.; CALIGIURI, P. Cultural distance, expatriate staffing and subsidiary performance: The case of US subsidiaries of multinational corporations. The International Journal of Human Resource Management, 19(2): 223-239, 2008.

COX, D.; OAKES, D, Analysis of Survival Data. CRC Press. 1984.

DAI, L.; EDEN, L.; BEAMISH, P. Place, space, and geographical exposure: Foreign subsidiary survival in conflict zones. Journal of International Business Studies, 44(6): 554-578, 2013.

DELIOS, A; BEAMISH, P. Survival and profitability: The roles of experience and intangible assets in foreign subsidiary performance. Academy of Management Journal, 44(5): 1028-1038, 2001.

DELIOS, A.; BEAMISH, P. Ownership strategy of Japanese firms: Transactional, institutional and experience influences. Japanese Subsidiaries in the New Global Economy Strategic Management Journal, 20(10): 915-933, 1999.

DELIOS, A.; HENISZ, W. Policy uncertainty and the sequence of entry by Japanese firms, 1980-1998. Journal of International Business Studies, 34(3): 227-241, 2003.

DELIOS, A.; HENISZ, W. Political hazards, experience, and sequential entry strategies: The international expansion of Japanese firms, 1980-1998. Strategic Management Journal, 24(11): 1153-1164, 2003.

DIKOVA, D. Performance of foreign subsidiaries: Does psychic distance matter? International Business Review, 18(1): 38-49, 2009.

DIMAGGIO, P.; POWELL, W. And collective rationality in organizational fields. American Sociological Review, 48(2): 147-160, 1983.

DOW, D.; LARIMO, J. Disentangling the Roles of International Experience and Distance in Establishment Mode Choice. Management International Review, 51(3), 321-355, 2011.

DUNNE, T.; ROBERTS, M. J.; SAMUELSON, L. Patterns of firm entry and exit in US manufacturing industries. The RAND Journal of Economics, 19(4): 495-515, 1988.

DUNNING, J. The eclectic (OLI) paradigm of international production: past, present and future. International Journal of the Economics of Business, 8(2): 173-190, 2001.

DUNNING, J. The eclectic paradigm of international production: a restatement and some possible extensions. Journal of International Business Studies, 19(1): 1-31, 1988.

DUNNING, J.; LUNDAN, S. M. Institutions and the OLI paradigm of the multinational enterprise. Asia Pacific Journal of Management, 25(4): 573-593, 2008. 
DUTTA, D.V.; BEAMISH, P.W. expatriate managers, product relatedness, and IJV performance: A resource and knowledge-based perspective. Journal of International Management, 19(2): 152-162, 2013.

EVANS, J.; MAVONDO, F. T. Psychic distance and organizational performance: An empirical examination of international retailing operations. Journal of International Business Studies, 33(0):515-532, 2002.

FANG, Y.; WADE, M.; DELIOS, A.; BEAMISH, P. An exploration of multinational enterprise knowledge resources and foreign subsidiary performance. Journal of World Business 48(1): 30-38, 2013.

FERREIRA, M. P.; FERREIRA, J. G. The impact of selected institutional environment dimensions of sub-Saharan countries on their ability to attract foreign direct investment. Internext, 11(1), 21-36, 2016.

FRANKEL, J.; ROSE, A. An estimate of the effect of common currencies on trade and income. Quarterly Journal of Economics, 117(2): 437-466, 2002.

GARCIA-CANAL, E.; GUILLÉN, M. Risk and the strategy of foreign location choice in regulated industries. Strategic Management Journal, 29(10): 1097-1115, 2008.

GARG, M.; DELIOS, A. Survival of the foreign subsidiaries of TMNCs: The influence of business group affiliation. Journal of International Management, 13(3): 278-295, 2007.

GAUR, A.; LU, J. Ownership strategies and survival of foreign subsidiaries: Impacts of institutional distance and experience. Journal of Management, 33(1): 84-110, 2007.

GERINGER, J.; HEBERT, L. Control and performance of international joint ventures. Journal of International Business Studies, 20(2): 235-254, 1989.

GHEMAWAT, P. Distance still matters: the hard reality of global expansion. Harvard Business Review, 79(8): 137-145, 2001.

GLAUM, M.; OESTERLE, M-J. 40 years of research on internationalization and firm performance: more questions than answers? Management International Review, 47(3): 307-317, 2007.

GOERZEN, A. Alliance networks and firm performance: The impact of repeated partnerships. Strategic Management Journal, 28(5): 487-509, 2007.

GOERZEN, A.; BEAMISH, P. Geographic scope and multinational enterprise performance. Strategic Management Journal, 24(13): 1289-1306, 2003.

GUILLÉN, M.; SUÁREZ, S. Explaining the global digital divide: Economic, political and sociological drivers of cross-national Internet use. Social Forces, 84(2): 681-708, 2005.

GULER, I.; GUILLÉN, M. Institutions and the internationalization of US venture capital firms. Journal of International Business Studies, 41(2): 185-205, 2010.

HARZING, A.-W. Acquisitions versus greenfield investments: International strategy and management of entry modes. Strategic Management Journal, 23(3): 211-227, 2002.

HENISZ, W. The institutional environment for economic growth. Economics \& Politics, 12(1): 1-31, 2000.

HENNART, J-F. The transaction costs theory of joint ventures: An empirical study of Japanese subsidiaries in the United States. Management Science, 37(4): 483-497, 1991.

HENNART, J-F.; LARIMO, J. The impact of culture on the strategy of multinational enterprises: does national origin affect ownership decisions? Journal of International Business Studies, 29(3): 515-538, 1998.

HOFSTEDE. Geert Hofstede. National Cultural Dimensions, 2010. Available in: < https://geert-hofstede. com> accessed 11 June 2015.

HUTZSCHENREUTER, T.; HORSTKOTTE, J. Performance effects of top management team demographic faultlines in the process of product diversification. Strategic Management Journal, 34(6):704-726, 2013.

HYMER, S. The international operations of national firms, a study of direct foreign investment, 14: 139-155. MA: MIT Press, 1960.

JACKSON, G.; DEEG, R. Comparing capitalisms: Understanding institutional diversity and its implications for international business. Journal of International Business Studies, 39(4): 540-561, 2008.

JAVERNICK-WILL, A.N. Organizational learning during internationalization: acquiring local institutional knowledge, Construction Management and Economics, 27(8): 783-797, 2009.

JIANG, R.J.: BEAMISH, P.W.; MAKINO, S. Time compression diseconomies in foreign expansion. Journal of World Business, 49(1): 114-121, 2014.

JOHANSON, J.; VAHLNE, J. The internationalization process of the firm-a model of knowledge development and increasing foreign market commitments. Journal of International Business Studies, 8(1): 23-32, 1977. 
BBR

15,3

KIRBY, J. Toward a theory of high performance. Harvard Business Review, 83(7): 30-39, 2005.

KOGUT, B.; SINGH, H. The effect of national culture on the choice of entry mode. Journal of International Business Studies, 19(3): 411-432, 1988.

KOSTOVA, T. Transnational transfer of strategic organizational practices: A contextual perspective. Academy of Management Review, 24(2): 308-324, 1999.

KOSTOVA, T., ROTH, K.; DACIN, M. Institutional theory in the study of multinational corporations: A critique and new directions. Academy of Management Review, 33(4): 994-1006, 2008.

KOSTOVA, T.; ZAHEER, S. Organizational legitimacy under conditions of complexity: The case of the multinational enterprise. Academy of Management Review, 24(1), 64-81, 1999.

KRISHNA, P. Are Regional Trading Partners "Natural"? Journal of Political Economy, 111(1): 202-226, 2003.

LA PORTA, R.; LÓPEZ-DE-SILANES, F.; SHLEIFER, A.; VISHNY, R. W. Law and finance. Journal of Political Economy, 106(6): 1113-1155, 1998.

LU, J.; BEAMISH, P. International diversification and firm performance: The S-curve hypothesis. Academy of Management Journal, 47(4): 598-609, 2004.

MA, X.; DELIOS, A. Anew tale of two cities: Japanese FDIs in Shanghai and Beijing, 1979-2003. International Business Review, 16(2): 207-228, 2007.

MALHOTRA, S.; SIVAKUMAR, K.; ZHU, P.C. Distance factors and target market selection: the moderating effect of market potential. International Marketing Review, 26(6): 651-673, 2009.

OGASAVARA, M. The effects of own-and other-prior entry modes in the internationalization of Japanese multinational companies in the electronic sector. Journal of Asia Business Studies, 8(1): 18-28, 2014.

OGASAVARA, M.; HOSHINO, Y. The effects of entry strategy and inter-firm trust on the survival of Japanese manufacturing subsidiaries in Brazil. Asian Business and Management, 7(3): 353-380, 2008.

PENG, G.; BEAMISH, P. The effect of host country long term orientation on subsidiary ownership and survival. Asia Pacific Journal of Management, 31(2): 423-453, 2014.

PENG, M. The global strategy of emerging multinationals from China. Global Strategy Journal, 2(2): 97$107,2012$.

PERKINS, S. E. When Does Prior Experience Pay? Institutional Experience and the Multinational Corporation. Administrative Science Quarterly, 59(1): 145-181, 2014.

POWELL, K.; RHEE, M. Experience in different institutional environments and foreign subsidiary ownership structure. Journal of Management, 42(6): 1434-1461, 2013.

RICHARD, P.J.; DEVINNEY, T.M.; YIP, G.S.; JOHNSON, G. Measuring organizational performance: Towards methodological best practice. Journal of Management, 35(3): 718-804, 2009.

ROMAN, D. J.; PIANA, J.; L. LOZANO, M. A. S.; MELLO, N. R.; ERDMANN, R. H. Fatores de competitividade organizacional. Brazilian Business Review, 9(1), 27-46, 2012.

SLANGEN, A. H. L.; HENNART, J.-F. Do multinationals really prefer to enter culturally distant countries through greenfields rather than through acquisitions? The role of parent experience and subsidiary autonomy. Journal of International Business Studies, 39(3): 472-490, 2008

SOHN, J. Social knowledge as a control system: A proposition and evidence from the Japanese FDI behavior. Journal of International Business Studies, 25(2): 295-324, 1994.

SONG, S. Entry mode irreversibility, host market uncertainty, and foreign subsidiary exits. Asia Pacific Journal of Management, 31(2): 455-471, 2014.

THE LAUDER INSTITUTE. The Lauder Institute. Available in: $<$ http://lauder.wharton.upenn.edu/resourcespublications $>$ accessed 10 June 2015.

TSANG, E. W.K; YIP, P. S.L. Economic distance and the survival of foreign direct investments. Academy of Management Journal, 50(5): 1156-1168, 2007.

UNCTAD. World Investiment Report Foreign, Direct Investment and Multinational Enterprises. http://unctad. org/en/PublicationsLibrary/wir2015_en.pdf United Nations. New York, acessed 02 June 2015

WAN, W. The performance implications of relationship banking during macroeconomic expansion and contraction: a study of Japanese banks' social relationships and overseas expansion. Journal of International Business Studies, 39(3): 406-427, 2008. 
WANG, Y.; LARIMO, J. Subsidiary Survival of Multinational Enterprises in China: An Analysis of Nordic Firms. The Rise of Multinationals from Emerging Economies: Achieving a New Balance. The Academy of International Business, Palgrave Macmillan UK, 135-158, 2015.

WHITLEY, R. Business systems in East Asia: Firms, markets and societies. Oxford University Press, 1992.

WILLIAMS, D.; GRÉGOIRE, D. Seeking commonalities or avoiding differences? Re-conceptualizing distance and its effects on internationalization decisions. Journal of International Business Studies, 46(5): 253-284, 2014.

XU, D.; SHENKAR, O. Note: Institutional distance and the multinational enterprise. Academy of Management Review, 27(4): 608-618, 2002.

YIU, D.; MAKINO, S. The choice between joint venture and wholly owned subsidiary: An institutional perspective. Organization Science, 13(6): 667-683, 2002.

ZHOU, N.; GUILLÉN, M. From home country to home base: A dynamic approach to the liability of foreignness. Strategic Management Journal, 36(6): 907-917, 2014. 